\title{
The Effects of International Sanctions on External Debt ${ }^{1}$ Uluslararası Yaptırımların Dış Borçlar Üzerine Etkileri \\ Atakan DURMAZ" \\ Ömer AKKUŞ***
}

\begin{abstract}
In this study, the effects of international sanctions imposed by the United States (US) and multinational institutions (European Union (EU) and the United Nations (UN)) on the external debts of less developed or/and developing countries are empirically assessed. Our sample includes 44 countries experienced international sanctions over the period 1976-2014. According to the results, the sanctions significantly increase the external debt of the target country. Moreover, if the targeted countries increase government expenditures against these sanctions, it is seen that the tendency of these sanctions to increase external debt is lower in sanctioned periods. Adding to these, the effect of the type of regime in targeted countries on external debt varies according to the state of government expenditures.
\end{abstract}

Keywords: Sanctions, external debt, developing countries, less developed countries

$\ddot{O} z$

$\mathrm{Bu}$ çalışmada, Amerika Birleşik Devletleri (ABD) ve çokuluslu kurumlar (Avrupa Birliği $(\mathrm{AB})$ ve Birleşmiş Milletler (BM)) tarafindan uygulanan uluslararası yaptırımların az gelişmiş ve gelişmekte olan ülkelerin dış borçlarına etkileri ampirik olarak değerlendirilmiștir. Bu kapsamda, uluslararası yaptırım uygulanan 44 ülkeye ait 1976-2014 dönemini kapsayan veriler kullanılmıştır. Elde edilen sonuçlara göre yaptırımlar, hedef ülkenin dış borcunu önemli ölçüde artırmaktadır. Ayrıca, hedeflenen ülkelerin bu yaptırımlara karşı devlet harcamalarını artırması halinde, bu yaptırımların dış borçlanmayı arttırma eğiliminin yaptırım dönemlerinde daha düşük olduğu görülmektedir. Bunlara ek olarak, hedeflenen ülkelerde rejimin türünün dış borçlara etkisi, hükümet harcamalarının durumuna göre değişmektedir.

Anahtar Kelimeler: Yaptırımlar, Dış Borç, Gelişmekte Olan Ülkeler, Az Gelişmiş Ülkeler

\section{Introduction}

Economic sanctions have recently become a tool used frequently in foreign politics. Many countries, especially the USA, apply to these sanctions for various purposes through unilateral or international institutions (Cortright and Lopez, 2000, Hufbauer et. al. 2009). Sanctions are often implemented by promoting democratic rights and freedoms, stopping civil wars, preventing the spread of nuclear weapons, and punishing states that provide assistance to global terrorists (Hatipoglu and Peksen, 2018). One of the most important reasons for the preference of these sanctions is to be seen as a non-violent and humanistic alternative to military intervention. Because economic sanctions aim to change the policies of the target country by inflicting it on the economy (Neuenkirch and Neumeier, 2016). Indeed, some studies in the literature document-that sanctions may be a adverse effect on the economic condition of the target country. In this respect, Neuenkirch and Neumeier (2015) and Hufbauer et al. (2009) are among the important studies showing the effects of economic sanctions on target country economies.

\footnotetext{
${ }^{1}$ An earlier version of this article was presented at the International Congress On Political, Economic And Social Studies (ICPESS2017), Sarajevo, Bosnia-Herzegovina, May 19-22, 2017.

* Dr. Öğr. Üyesi, Bayburt Üniversitesi, İktisadi ve İdari Bilimler Fakültesi, İktisat Bölümü, adurmaz@bayburt.edu.tr

*** Dr. Öğr. Üyesi, Gümüşhane Üniversitesi, İktisadi ve İdari Bilimler Fakültesi, İktisat Bölümü, omerakkus@gumushane.edu.tr
}

Durmaz, A \& Akkuş, Ö. (2019). The Effects of International Sanctions on External Debt, Gaziantep University Journal of Social Sciences, 18(2), 662-673, Submission Date: 22-11-2018, Acceptance Date: 14-03-2019. Araştırma Makalesi. 
When the consequences of economic sanctions are examined, it appears that the vast majority of applications fail to achieve their aims (Hufbauer et al. 2009, Pape 1998). Moreover, it has been found that these sanctions do not only fail to achieve the intended objectives, but also cause considerable human and political harm in the target societies (Neuenkirch and Neumeier, 2016). This leads to some criticism of the implementation of economic sanctions. The most criticized issue is that most of the cost of sanctions is borne by the people in the target country, although the measures taken are generally directed to governments. specially if the target country is being managed on non-democratic conditions, the cost of sanctions can be reflected in the mass of the society.

As a matter of fact, there are many studies in the literature on the negative effects of sanctions on the humanitarian conditions of the target countries. In this context, some studies have indicated that the society will adversely affect access to adequate clean water and food resources (Weiss et al. 1997, Cortright and Lopez, 2000), while others emphasize that the same is the case with access to medical and health services (Weiss 1999, Gibbons and Garfield 1999, Garfield 2002, Peksen 2011, Allen and Lektzian, 2013). In some studies it has been shown that sanctions are a negative effect on infant mortality and life expectancy (Ali and Shah 2000, Daponte, and Garfield, 2000).

Some studies-indicate that sanctions are not only negative effects on the human conditions of the target countries, but also on the political structure. From these studies, Wood (2008), Peksen (2009) and Oechslin (2014) point out how economic sanctions affected the human rights in the target countries; Marinov (2005), Allen (2008) and Escribà-Folch and Wright (2010) point out sanctions affect the political stability of the target country and Peksen and Drury (2010) focuses on the effects of sanctions on target country's democracy level.

Empirical studies on the effects of economic sanctions on economies of target countries are less common. In this context, Evenett (2002) and Hufbauer et al. (2009) focused on the effects of economic sanctions on the foreign trade of the target countries, while Dizaji \& van Bergeijk (2013) investigated the negative effects of sanctions on various macroeconomic indicators. Neuenkirch \& Neumeier (2015) have examined the effects of economic sanctions on the economic growth of the target countries.

This paper contributes to the literature by providing a empirical assessment of how economic sanctions affect the external debt of the target countries. Economic sanctions often cause a recession in exports and imports, as well as the withdrawal of foreign aid and investments (Weiss et al. 1997, Heine-Ellison, 2001). As a result of the sanctions, even if the investments are not withdrawn, the increase in political risk in the target country may increase the borrowing costs of the target countries. This can lead to serious economic problems, especially in terms of underdeveloped and developing countries needing foreign capital to sustain economic growth. According to our research, In the researches, there was no literature that directly assessed the effect of economic sanctions on the external debt stock of the target states. In this respect, it is expected that this study will contribute to the literature by revealing the effects of economic sanctions effects on the external debts of the target countries.

The study prepared in this direction consists of four main sections. Section 2 presents an overview of theoretical framework and the related literature. Section 3 presents the 
methodology being used in this study and discusses the method used in analyzing the data. The conclusions of study are presented in Section 4.

\section{Literature Review}

In general, it can be said that economic sanctions are obligatory measures between military intervention and diplomatic oppression, including various actions such as tariffs, export controls, import restrictions, travel restrictions, freezing assets, reduction or elimination of foreign aid and withdrawal of diplomatic relations. Theoretically, economic sanctions are influential because of the potential for economic harm. As a matter of fact, economic sanctions often affect the target country's economy in the form of negative external shocks. These external shocks are often causing huge costs on the economy by increasing unemployment and inflation reducing economic output and. Hufbauer (2009) finds that target countries are confronted a 3 per cent decline in average GDP in their study of a comprehensive assessment of all major economic sanctions since the beginning of the twentieth century. It also indicates that the average inflation rate during the years of sanctions is approximately 37\%, excluding countries with high inflation. Similarly, Neuenkirch and Neumeier, (2015) found that economic sanctions imposed by the and the USA (United States) and UN (United Nations) on 68 different countries have created negative macroeconomic effects on target countries. According to the results, it was determined that sanctions in the USA led to an average decrease of about $1 \%$ in real GDP, while UN sanctions reduced the target countries GDP by $2.8 \%$ on average.

The effects of economic sanctions are not only on the goods and services sector, but also on the financial sector. The contraction in the economy due to sanctions may cause decreases in the funds deposited in the bank. In order to minimize their risk, investors can turn their savings into alternative sectors other (such as government bonds) than the banking system. This type of deposit constraint forces banks to raise nominal deposit rates in order to attract more funds, while the rise in nominal deposit rates causes the banks to lose their profitability. Because the nominal return of most bank assets is fixed or the rising fund does not keep up with the cost. As a result, increasing funding costs increase the likelihood of bankruptcy in the banking sector and lay the groundwork for the emergence of banking crises (Demirgüç-Kunt and Detragiache 1997, Diamond and Rajan, 2012).

There are various channels through which sanctions can affect the economic structure of the target country negatively. Within these channels, it is possible to say such means as export and import restrictions, declining competitive power in international markets and reduction of international capital movements (reduction of foreign direct investment, withdrawal of foreign aid and financial grants etc.) (Evenett 2002, Hufbauer et al. 2009). However, even if commercial embargoes or suspension of international aid and capital flows are not explicitly prohibited, such adverse effects may arise and in some cases even discourses of economic sanctions are effective on the target country (Whang, 2011). These discourses may cause the target country to lose its reputation, or it may lose its position in the international community and lead to a decrease in external support.

On the other hand, the fact that economic sanctions are aimed at making political reforms and even changing political power is a serious threat to the political stability of the 
target country. This can create a great uncertainty about the future of the political system and the political elite. It is expected that this ambiguity will have a negative effect on the commercial and financial relations of the target state and direct investments in the target state (Hatipoglu and Peksen, 2018). Indeed, empirical research shows that economic sanctions are associated with the transitional process and political turmoil (Peksen and Drury, 2010, Marinov 2005, Allen, 2008). Studies have shown that political instability has negative effects on both investment and saving and economic growth (Aizenman and Marion 1993, Alesina et al. 1996, Alesina and Perotti, 1996). However, the effects of these economic sanctions on the economy of the target country depend on various factors. One of these factors is the effectiveness of the sanction instrument used by the organization or country that implements economic sanctions. Among the past practices of the United Nations and the United States are many tools, from stopping the movements of funds and assets, to prohibiting grants and loans, to maintaining all economic activities. Whoever applies economic sanctions to the target country also changes the effectiveness of sanctions. It can be argued that the sanctions of international organizations (United Nations, European Union), where more than one country is involved, have a superior negative effect on the growth of GDP of the target country compared to the sanctions of unilateral countries (Neuenkirch and Neumeier, 2015). In addition, if the sanction is the sole country, the target country may avoid losing access to raw materials or access to alternative trading partners. However, it should not be overlooked that working with alternative trading partners can sometimes have the disadvantage of being away from optimal trade conditions.

Another factor that determines the effects of economic sanctions on the target country is the political and economic structure of the target country. In this direction, Marinov (2005) states that sanctions are two different effects on the target country. The first of these effects is the sanctioned costs that political power and its supporters must bear; and the second is the sanitary costs that the rest of society must undertake. Hence, it can be said that economic sanctions usually have a heterogeneous effect. Individuals living in society are able to reduce the negative effects of sanctions depending on their political ties and connections (Kaempfer and Lowenberg, 2007). Studies indicate that this situation may adversely affect income distribution in the target country. As a matter of fact, Neuenkirch and Neumeier (2016) found that the economic sanctions imposed by the USA have different effects according to income distribution in the target countries. According to the results of the study, those with low income levels are more affected by economic sanctions.

Economic sanctions also have negative effects on debtors. Previous research has shown that in periods of adverse macroeconomic conditions such as economic contraction, the likelihood of firms defaulting on their debts increases due to declining rates of profit and other difficulties (Lindgren et al. 1996, Kaminsky and Reinhart, 1999; Demirguc and Detragiache, 2000).

A similar situation applies to countries. Countries that are the targets of international sanctions are often underdeveloped or developing countries that often try to achieve economic growth by investing in foreign capital and often have a high external debt burden. This can lead to serious problems in paying the external debt of target countries. In the economic literature, the relationship between international sanctions and the sovereign defaults is 
expressed in terms of "gunboat diplomacy" and "supersanctions" (Weidenmier, 2005). In the related literature, there are two different approaches to explain the subject. The general opinion in the literature suggests that international sanctions are intended to encourage debt repayment through the serious and long-term economic costs that the target country is exposed to. In other words, the failure of the countries to pay their debts causes sanctions. Although this approach is valid in many cases, according to the other approach, sanctions cause countries to be unable to pay their debts (Scheresberg et al. 2017).

In some countries where economic sanction is applied, political power is trying to win community support by resisting these sanctions. In this context, they try to take public support in the short term by reducing the costs of economic sanctions on society. One of the policies frequently referred to during these periods is expansionary fiscal policies. Political power aims to increase total demand by increasing government expenditures and thus revitalize the economy which is narrowing as a result of sanctions. In this sense, it can be said that government expenditure has function of reducing the effect of economic sanctions. Therefore, we hypothesize that:

\section{$H_{1}$ : There is a positive effect of economic sanctions on external debt stocks \\ $\mathrm{H}_{2}$ : Government expenditures reduce the impact of economic sanctions on external debt stocks}

\section{Method, Data and Empirical Results}

\section{Method and Data}

The different versions of the following model are estimated in this study to reveal the impact of the economic sanctions imposed by any of the United States, the European Union and the United Nations on the external debt of the target country.

$$
y_{i, t}=\alpha_{i}+\beta X_{i, t}+\delta_{t}+\varepsilon_{i, t}
$$

The independent variable $\left(y_{i, t}\right)$ is the external debt, independent variables $\left(X_{i, t}\right)$ represent sanctions, government expenditure, inflation, GDP per capita, the type of regime, secondary school enrollment, $\alpha_{i}$ individual specific effect which explains individual heterogeneity due to the unobservable and time-invariant factors, $\delta_{t}$ time effect and $\varepsilon_{i, t}$ error term. The study examines 44 countries $^{1}$ sanctioned by the United States, the European Union and the United Nations the period 1976-2014.

The descriptive statistics of the variables used in the model are shown in Table 1.

Table 1: Descriptive Statistics

\begin{tabular}{lccccc}
\hline Variable & Obs & Mean & Std.Dev. & Min & Max \\
\hline External Debt & 1,500 & 67.56185 & 106.7443 & 0.463434 & 1380.77 \\
\hline Sanctions & 1,657 & 0.336753 & 0.4727424 & 0 & 1
\end{tabular}

\footnotetext{
1 Angola, Azerbaijan, Belarus, Bolivia, Brazil, Cambodia, Cameroon, Central African Republic, China, Colombia, Ecuador, Ethiopia, Fiji, Gambia, Guinea, Guatemala, India, Indonesia, Iran Islamic Rep., Jordan, Kenya, Liberia, Lebanon, Malawi, Nicaragua, Nigeria, Niger, Pakistan, Paraguay, Peru, Romania, Rwanda, South Africa, El Salvador, Sudan, Syrian Arab Republic, Thailand, Turkey, Uganda, Uzbekistan, Vietnam, Yemen Rep., Zambia, Zimbabwe
} 


\begin{tabular}{lccccc}
\hline Gov.Expenditure & 1,452 & 13.78877 & 5.901332 & 1.37519 & 54.5154 \\
\hline Inflation & 1,561 & 72.44044 & 577.8561 & -27.0486 & 13611.6 \\
\hline Gdppercapita & 1,542 & 2400.484 & 2281.689 & 115.436 & 11797.4 \\
\hline Type of regime & 1,656 & 1.274155 & 0.6464095 & 1 & 4 \\
\hline Schoolenrollment & 1,546 & 5080.337 & 15273.4 & 3 & 119148 \\
\hline
\end{tabular}

The data belonging variables is obtained from United Nations Statistical Databases, World Development Indicator and Cross National Time Series Data Archive. A large part of the data on sanctions has been used in comparison with the data compiled by Wood (2008).

The general government expenditure includes all government current expenditures for goods and services purchases and is used as a percentage of the gross domestic income while external debt stock is used as a percentage of gross national income. The inflation measured by the annual growth rate of the gross domestic product deflator reflects the rate of price change in the economy as a whole. Gross domestic product per capita is used as the constant 2010 US dollar.

The sanction variable is set down as a dummy variable and this variable has a value of 1 for years sanctioned by the United States, the European Union or the United Nations, and 0 for other years. Type of regime takes values from 1 to 4 . When type of regime takes a value of 1 , it is a civilian government whose population is controlled by a non-military component. The external appearance controlled by a military elite when it gets the value of 2 is a civilian government. When it takes the value of 3 , it is usually (but it is not compulsory) directly managed by the military after a military coup d'état. when it gets the value of 4 , it is called the others and the first three type of regimes counted represent regime that cannot be included in any one of them, that is, the fact that they cannot have a strong national government due to external influences. The model results are obtained by using the panel data method for the data set compiled by considering the country number and the time dimension. The panel data method is applied in the study and three of the model results of Pooled OLS, fixed effects and random effects are estimated in different formations and are shown in the model results. However, it should be noted that constant terms and error terms must be mutually independent in the random effects model when model results are reported.

\section{Empirical Results}

Three different versions of the model given in equation (1) have been estimated. The results are presented in Table 2, Table 3 and Table 4. The factor behind estimating the model in the different versions is that some of variables considered in the model might have a large effect on the increase or decrease in external debt. Government expenditures and type of regime variables are notable among these variables. The estimation results that these two variables are jointly included in the model are presented in Table 2.

Table 2 indicates the results that all of the control variables are included in the model. All of the estimation methods used indicate that sanctions are positively and statistically significant on external debt at $1 \%$ significance level. This means that when all the control variables are included in the model, the sanctions imposed on the countries increase the external debt of the target country much more and it indicates that an increase in sanctions increases the external debt of the target country about $28 \%$. It also indicates that an increase in 
government expenditures increase the external debt of the target country about $2 \%$ when the control variables are examined. On the other hand, it is determined that an increase in inflation rates is a variable increasing external debt and this effect remaines at low levels. However, secondary school enrollment and type of regime are not found statistically meaningful.

Table 2: Empirical Results (All Variables)

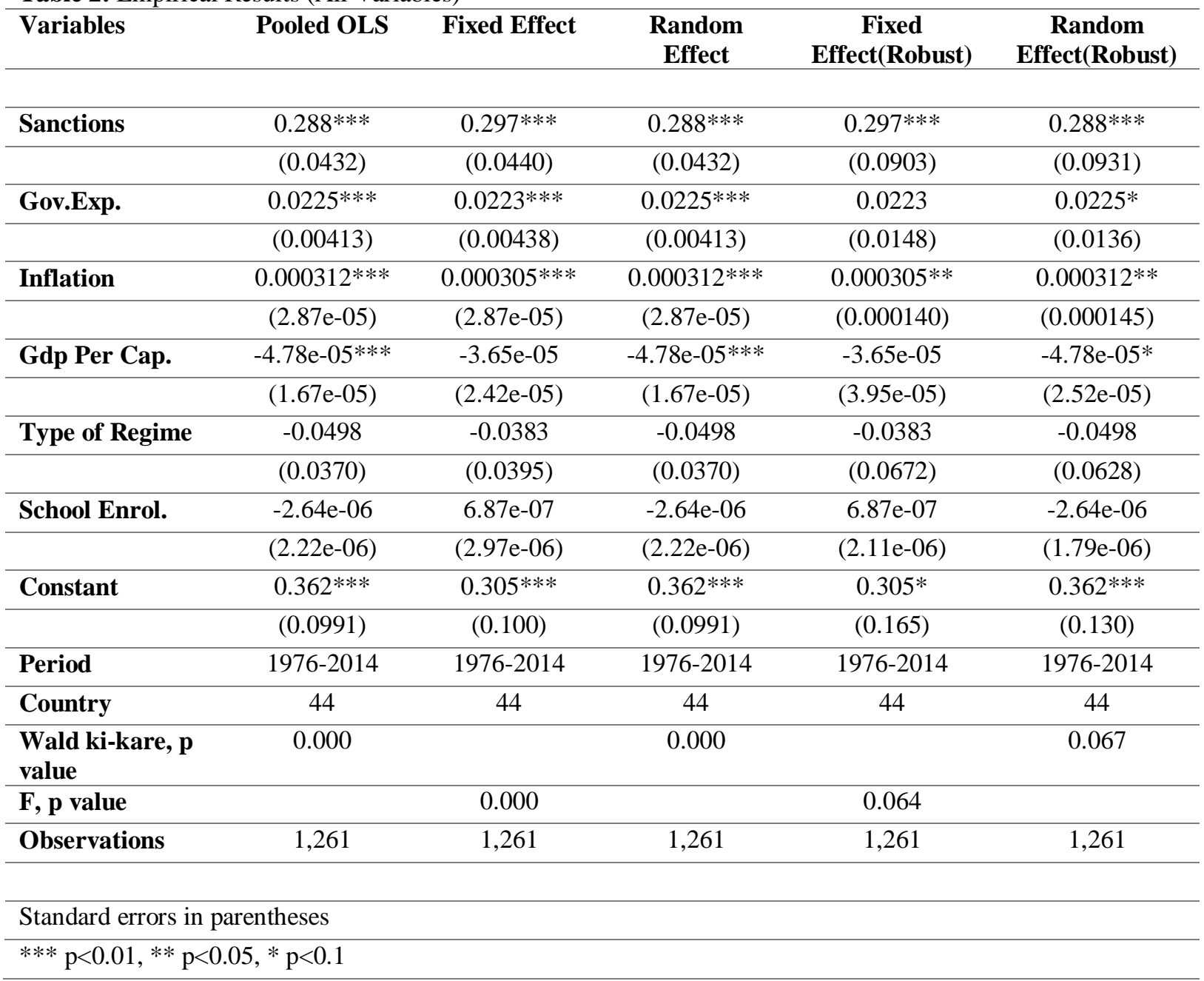

Namely, the fact that the regime in the country is a civilian government controlled by a non-military component or that it is directly governed by the army is not statistically significant if all of the control variables are included in the model. Nevertheless, the results indicate that external debt of target country decrease if GDP per capita in target country increase. The estimated model results in case government expenditure is excluded are presented in Table 3. 
Table 3: Empirical Results (Excluded Government Expenditure)

\begin{tabular}{|c|c|c|c|c|c|}
\hline VARIABLES & Pooled & Fixed & Random & $\begin{array}{c}\text { Fixed } \\
\text { (Robust) }\end{array}$ & $\begin{array}{l}\text { Random } \\
\text { (Robust) }\end{array}$ \\
\hline \multirow[t]{2}{*}{ Sanctions } & $0.333 * * *$ & $0.345 * * *$ & $0.333 * * *$ & $0.345 * * *$ & $0.333 * * *$ \\
\hline & $(0.0475)$ & $(0.0481)$ & $(0.0475)$ & $(0.115)$ & $(0.114)$ \\
\hline \multicolumn{6}{|l|}{ Gov.Exp. } \\
\hline \multirow[t]{2}{*}{ Inflation } & $0.000319 * * *$ & $0.000312 * * *$ & $0.000319 * * *$ & $0.000312 * *$ & $0.000319 * *$ \\
\hline & (3.11e-05) & $(3.11 \mathrm{e}-05)$ & $(3.11 \mathrm{e}-05)$ & $(0.000152)$ & $(0.000155)$ \\
\hline \multirow[t]{2}{*}{ Gdp Per Cap. } & $-6.43 e-05 * * *$ & $-6.75 \mathrm{e}-05^{* *}$ & $-6.43 \mathrm{e}-05 * * *$ & $-6.75 e-05$ & $-6.43 e-05 *$ \\
\hline & $(2.05 e-05)$ & $(2.71 \mathrm{e}-05)$ & $(2.05 e-05)$ & $(5.29 \mathrm{e}-05)$ & $(3.44 \mathrm{e}-05)$ \\
\hline \multirow[t]{2}{*}{ Type of Regime } & $-0.110 * * *$ & $-0.109 * *$ & $-0.110 * * *$ & -0.109 & -0.110 \\
\hline & $(0.0409)$ & $(0.0426)$ & $(0.0409)$ & $(0.0853)$ & $(0.0756)$ \\
\hline \multirow[t]{2}{*}{ School Enrol. } & $-1.91 \mathrm{e}-06$ & $1.97 \mathrm{e}-06$ & $-1.91 e-06$ & $1.97 \mathrm{e}-06$ & $-1.91 \mathrm{e}-06$ \\
\hline & $(2.70 \mathrm{e}-06)$ & $(3.35 \mathrm{e}-06)$ & $(2.70 \mathrm{e}-06)$ & $(2.46 \mathrm{e}-06)$ & $(1.95 \mathrm{e}-06)$ \\
\hline \multirow[t]{2}{*}{ Constant } & $0.823 * * *$ & $0.798 * * *$ & $0.823 * * *$ & $0.798 * * *$ & $0.823 * * *$ \\
\hline & $(0.101)$ & $(0.0879)$ & $(0.101)$ & $(0.163)$ & $(0.181)$ \\
\hline Period & 1976-2014 & 1976-2014 & 1976-2014 & 1976-2014 & 1976-2014 \\
\hline Country & 43 & 43 & 43 & 43 & 43 \\
\hline $\begin{array}{l}\text { Wald ki-kare, p } \\
\text { value }\end{array}$ & 0.000 & & 0.000 & & 0.069 \\
\hline F, p value & & 0.000 & & 0.0804 & \\
\hline Observations & 1,346 & 1,346 & 1,346 & 1,346 & 1,346 \\
\hline \multicolumn{6}{|c|}{ Standard errors in parentheses } \\
\hline \multicolumn{6}{|c|}{$* * * \mathrm{p}<0.01, * * \mathrm{p}<0.05, * \mathrm{p}<0.1$} \\
\hline
\end{tabular}

Table 3 shows that sanctions affect the external debt of the target country at a higher rate according to Table 3 if government expenditure is not included in the model.

In the model with government expenditures, an increase in sanctions rises the external debt by around $28 \%$, but if this variable is excluded from the model, the estimation results indicates that the sanctions increase the external debt of the target country about $33 \%$. In a similar way, it is determined that secondary school enrollment does not have any significant effect on the external debt whereas inflation increased external debt but the effect on external debt was low. There is a statistically significant effect of type of regime when government expenditure is excluded from the model while type of regime is not a significant effect on external debt when all the control variables are involved in the model. In this case, the results clearly indicate that external debt decreases in countries where there is a transition from the civil government to directly managed by the military. While there is no significant effects in the models with adjusted standard errors, there is significant effects in other models for type of regime and this situation decrease external debt of target country about $10 \%$.

Table 4: Empirical Results (Excluded Type of Regime)

\begin{tabular}{lccccc}
\hline VARIABLES & Pooled OLS & Fixed & Random & $\begin{array}{c}\text { Fixed } \\
\text { (Robust) }\end{array}$ & $\begin{array}{c}\text { Random } \\
\text { (Robust) }\end{array}$ \\
\hline Sanctions & & & & & \\
\hline & $0.281^{* * *}$ & $0.293^{* * *}$ & $0.281^{* * *}$ & $0.293^{* * *}$ & $0.281^{* * *}$ \\
\hline & $(0.0429)$ & $(0.0437)$ & $(0.0429)$ & $(0.0871)$ & $(0.0895)$ \\
\hline
\end{tabular}




\begin{tabular}{|c|c|c|c|c|c|}
\hline \multirow[t]{2}{*}{ Gov.Exp. } & $0.0226 * * *$ & $0.0223 * * *$ & $0.0226 * * *$ & 0.0223 & $0.0226^{*}$ \\
\hline & $(0.00412)$ & $(0.00438)$ & $(0.00412)$ & $(0.0147)$ & $(0.0135)$ \\
\hline \multirow[t]{2}{*}{ Inflation } & $0.000314 * * *$ & $0.000306 * * *$ & $0.000314 * * *$ & $0.000306 * *$ & $0.000314 * *$ \\
\hline & $(2.87 e-05)$ & $(2.87 \mathrm{e}-05)$ & $(2.87 \mathrm{e}-05)$ & $(0.000140)$ & $(0.000146)$ \\
\hline \multirow[t]{2}{*}{ Gdp Per Cap. } & $-4.65 \mathrm{e}-05^{* * *}$ & $-3.45 e-05$ & $-4.65 \mathrm{e}-05 * * *$ & $-3.45 e-05$ & $-4.65 e-05^{*}$ \\
\hline & $(1.66 \mathrm{e}-05)$ & $(2.40 \mathrm{e}-05)$ & $(1.66 \mathrm{e}-05)$ & $(3.83 \mathrm{e}-05)$ & $(2.46 \mathrm{e}-05)$ \\
\hline \multicolumn{6}{|l|}{ Type of Regime } \\
\hline \multirow[t]{2}{*}{ School Enrol. } & $-2.49 \mathrm{e}-06$ & $8.41 \mathrm{e}-07$ & $-2.49 \mathrm{e}-06$ & $8.41 \mathrm{e}-07$ & $-2.49 \mathrm{e}-06$ \\
\hline & $(2.20 \mathrm{e}-06)$ & $(2.96 \mathrm{e}-06)$ & $(2.20 \mathrm{e}-06)$ & $(2.09 \mathrm{e}-06)$ & $(1.76 \mathrm{e}-06)$ \\
\hline \multirow[t]{2}{*}{ Constant } & $0.296^{* * *}$ & $0.251 * * *$ & $0.296 * * *$ & 0.251 & $0.296 *$ \\
\hline & $(0.0857)$ & $(0.0841)$ & $(0.0857)$ & $(0.198)$ & $(0.154)$ \\
\hline Period & $1976-2014$ & $1976-2014$ & $1976-2014$ & 1976-2014 & $1976-2014$ \\
\hline Country & 42 & 42 & 42 & 42 & 42 \\
\hline $\begin{array}{l}\text { Wald ki-kare, p } \\
\text { value }\end{array}$ & 0.000 & & 0.000 & & 0.039 \\
\hline F, p value & & 0.000 & & 0.043 & \\
\hline Observations & 1,262 & 1,262 & 1,262 & 1,262 & 1,262 \\
\hline \multicolumn{6}{|c|}{ Standard errors in parentheses } \\
\hline \multicolumn{6}{|c|}{$* * * \mathrm{p}<0.01, * * \mathrm{p}<0.05, * \mathrm{p}<0.1$} \\
\hline
\end{tabular}

It is determined the estimation results that type of regime is removed from the model are the similar to estimation results of those model with all control variables. According to Table 2, Table 3 and Table 4, secondary school enrollment has no significant effect on external debt in any models but type of regime has in a model which the government expenditure variable is excluded.

\section{Conclusion}

Although the sanctions are generally implemented on the grounds that the rights and freedoms of civilians are protected, they are used as an important tool to meet the demands of the countries that are subject to the sanction and which leaves the target country in a difficult situation in the international relations. Therefore, sanctions become a frequently used tool to create change in the targeted countries and lead to different effects on their economies. Countries or organizations implementing sanctions can put these sanctions into practice by recognizing that unwanted and harmful consequences may arise in the targeted country's economies. There will be a contraction in foreign trade volume as long as the target countries do not meet the demands of those who enforce sanctions. These and similar results lead to further increases in deficits in both the budget and foreign trade of the countries and countries begin to borrow for covering these deficits. The study empirically demonstrates that there is a significant increase in the external debt of the targeted countries in the sanctioned countries during the sanctioned periods and it suggests that the macroeconomic balances of the target country are tried to be influenced in the long run.Findings show that the sanctions significantly increase the external debt of the target country and indicates that if the targeted countries increase government expenditures against these sanctions, the tendency of these sanctions to increase external debt is observed to be lower in sanctioned periods. Nonetheless, the type of regime in the country is not a very important variable if government expenditures 
are taken into account but it is an important variable when government expenditures are not taken into consideration and the empirical evidence indicates that external debt of target country diminishes as it moves away from being democratic country. The negative effect of sanctions on the economies of target countries can be reduced if they can increase gross domestic product per capita in their own countries and the results of study Show that an increase in the gross domestic product per capita reduces the external debt of the countries targeted. As a result, it would not be wrong to emphasize that sanctions increase the external dependency of the targeted countries through external debt.

\section{References}

Aizenman, Joshua, and Nancy P. Marion. (1993). "Policy uncertainty, persistence and growth." Review of International Economics 1 (2): 145-63. https://doi.org/10.1111/j.1467-9396.1993.tb00012.x.

Alesina, A., Özler, S., Roubini, N., Swagel, P. (1996). "Political instability and economic growth." Journal of Economic Growth 211: 189-90.

Alesina, Alberto, and Roberto Perotti. (1996). "Income Distribution, Political Instability, and Investment." European Economic Review 40 (6): 1203-28. https://doi.org/10.1016/00 14-2921(95)00030-5.

Ali, Mohamed M, and Iqbal H Shah. (2000). "Sanctions and childhood mortality in Iraq." The Lancet 355 (9218): 1851-57. https://doi.org/10.1016/S0140-6736(00)02289-3.

Allen, Susan Hannah. (2008). "The Domestic political costs of economic sanctions." Journal of Conflict Resolution 52 (6): 916-44. https://doi.org/10.1177/0022002708325044.

Allen, Susan Hannah, and David J. Lektzian. (2013). "Economic sanctions: A blunt instrument?" Journal of Peace Research 50 (1): 121-35. https://doi.org/10.1177/0022 343312456224.

Cortright, D., Lopez, G. (2000). The sanctions decade: Assessing UN strategies in the 1990s. Edited by G. Cortright, D., Lopez. Boulder, CO.: Lynne Rienner.

Daponte, B., Garfield, R. (2000). "The effect of economic sanctions on the mortality of Iraqi children prior to the 1991 Persian Gulf War." American Journal of Public Health 90 (4): 546-52. https://doi.org/10.2105/AJPH.90.4.546.

Demirgüç-Kunt, Asli, and Enrica Detragiache. (1997). "The determinants of banking crises: Evidence from developing and developed countries." IMF Working Papers 97 (106): 1. https://doi.org/10.5089/9781451947175.001.

Demirguc, Ash, and Enrica Detragiache. (2000). "Monitoring banking sector fragility: A multivariate logit approach.” The World Bank Economic Review 14 (2): 287-307.

Diamond, Douglas W, and Raghuram Rajan. (2009). "Illiquidity and interest rate policy," no. National Bureau of Economic Research.

Diamond, Douglas W, and Raghuram G Rajan. (2012). "Illiquid banks , financial stability , and interest rate policy" 120 (3): 552-91.

Dizaji, Sajjad Faraji, and Peter A G van Bergeijk. (2013). "Potential early phase success and ultimate failure of economic sanctions." Journal of Peace Research 50 (6): 721-36. https://doi.org/10.1177/0022343313485487. 
Escribà-Folch, Abel, and Joseph Wright. (2010). "Dealing with tyranny: International sanctions and the survival of authoritarian rulers1." International Studies Quarterly 54 (2): 335-59. https://doi.org/10.1111/j.1468-2478.2010.00590.x.

Evenett, S.J. (2002). "The impact of economic sanctions on south African exports." Scottish Journal of Political Economy 49: 557-73. https://doi.org/https://doi.org/10.1111/14679485.00248.

Garfield, R. (2002). "Economic sanctions, humanitarianism and conflict after the Cold War." Social Justice 29 (3(89)): 94-107.

Gibbons, Elizabeth, and Richard Garfield. (1999). "The impact of economic sanctions on health and human rights in Haiti, 1991-1994." American Journal of Public Health 89 (10): 1499-1504. https://doi.org/10.2105/AJPH.89.10.1499.

Hatipoglu, Emre, and Dursun Peksen. (2018). "Economic sanctions and banking crises in target economies." Defence and Peace Economics 29 (2): 171-89. https://doi.org/10.1080/10 242694.2016.1245811.

Heine-Ellison, S. (2001). "The impact and effectiveness of multilateral economic sanctions: A comparative study." The International Journal of Human Rights 5 (1): 81-112. https:// doi.org/10.1080/714003707.

Hufbauer, G., Schott, J., Elliott, K.A., Oegg, B. (2009). Economic sanctions reconsidered: history and current policy. 3rd ed. Washington, DC: Institute for International Economics.

Kaempfer, William H., and Anton D. Lowenberg. (2007). "The political economy of economic sanctions." In Handbook of Defense Economics, Sandler, T. and Hartley K. (ed)., 2nd ed., 867-911. https://doi.org/10.1016/S1574-0013(06)02027-8.

Kaminsky, Graciela L, and Carmen M Reinhart. (1999). "The twin crises: The causes of banking and balance-of-payments problems." American Economic Review 89 (3): 473-500. https://doi.org/10.1257/aer.89.3.473.

Lindgren, Carl-Johan, Gillian G. Garcia, and Matthew I. Saal. (1996). Bank soundness and macroeconomic policy. Washington, DC: International Monetary Fund.

Marinov, Nikolay. (2005). "Does pressure from the outside destabilize leaders on the Inside." American Journal of Political Science 49 (3): 564-576.

Neuenkirch, Matthias, and Florian Neumeier. (2015). "The impact of UN and US economic sanctions on GDP growth." European Journal of Political Economy 40: 110-25. https://doi.org/10.1016/j.ejpoleco.2015.09.001.

(2016). "The impact of US sanctions on poverty." Journal of Development Economics 121: 110-19. https://doi.org/10.1016/j.jdeveco.2016.03.005.

Oechslin, Manuel. (2014). "Targeting autocrats: economic sanctions and regime change." European Journal of Political Economy 36 (December): 24-40. https://doi.org/10.1016 /j.ejpoleco.2014.07.003.

Pape, A. R. (1998). "Why economic sanctions still do not work." International Security 23 (1, Summer): 66-77. https://doi.org/10.2307/2539263.

Peksen, Dursun. (2009). "Better or worse? The effect of economic sanctions on human rights." Journal of Peace Research 46 (1): 59-77. https://doi.org/10.1177/0022343308098404. 
. (2011). "Economic sanctions and human security: The public health impact of Economic Sanctions.” Foreign Policy Analysis 7 (3): 237-51.

Peksen, Dursun, and A. Cooper Drury. (2010). "Coercive or Corrosive: The Negative Impact of Economic Sanctions on Democracy." International Interactions 36 (3): 240-64. https://doi.org/10.1080/03050629.2010.502436.

Scheresberg, Carlo de Bassa, Edoardo Grillo, and Francesco Pasarelli. (2017). "Sanctions and Incentives to Repudiate External Debt." Collegio Carlo Alberto. 505.

Weiss, T., Cortright, D., Lopez, G., Minear, L. (1997). Political Gain and Civilian Pain: Humanitarian Impacts of Economic Sanctions. Boulder, CO.: Rowman and Littlefield.

Weiss, Thomas G. (1999). "Sanctions as a Foreign Policy Tool: Weighing Humanitarian Impulses." Journal of Peace Research 36 (5): 499-509. https://doi.org/https://doi.org/ $10.1177 / 0022343399036005001$.

Whang, Taehee. (2011). "Playing to the Home Crowd? Symbolic Use of Economic Sanctions in the United States1.” International Studies Quarterly 55 (3): 787-801. https://doi.org /10.1111/j.1468-2478.2011.00668.x.

Wood, Reed M. (2008). “"A Hand upon the Throat of the Nation': Economic Sanctions and State Repression, 1976-2001." International Studies Quarterly 52 (3): 489-513. https:// doi.org/10.1111/j.1468-2478.2008.00512.x. 